\title{
Investigating the Effects of Word Games on Iranian EFL Learners' Application of the Words in Writing Paragraph Essays
}

\author{
Fatemeh Rezapanah \\ Department of English, South Tehran Branch \\ Islamic Azad University, Tehran, Iran \\ E-mail: fatemehrezapanah@yahoo.com \\ Hadi Hamidi (Corresponding author) \\ Department of English, Science and Research Branch \\ Islamic Azad University, Mazandaran, Iran \\ E-mail: hamidi_tefl@yahoo.com
}

Received: 28-07- 2012

Accepted: 13-09- 2012

Published: 01-01- 2013

doi:10.7575/ijalel.v.2n.1p.35

URL: http://dx.doi.org/10.7575/ijalel.v.2n.1p.35

\begin{abstract}
In Iran, learning vocabulary has been considered a boring subject for a long time and the traditional way of learning vocabulary by mere copying and remembering has shown to be less than effective. Meanwhile, games are also seen as a time-filling activity in most English classrooms. The current research sought to explore the effectiveness of using word games on Iranian EFL intermediate students' application of the words in writing one paragraph essay. It was carried out at Jahad Sharif English Institute among 60 intermediate male and female learners with the age range of 17-30 through a quasi-experimental research design. The researcher administered a PET test to determine the homogeneity of the participants regarding their general English language proficiency level. Participants were randomly assigned into two groups. After coming up with the conclusion that the two groups were homogeneous, during 16 sessions of treatment, the experimental group was taught using different techniques of word games while the control group received no special treatment. At the end of the treatment, both groups participated in the word game writing test of the word game questions available in Top Notch series the post-test. A t-test was used to compare the mean scores of the two groups, the result of which showed that the learners' mean score in the experimental group was significantly higher than the learners' mean score in the control group. In conclusion, the result of this study suggests that foreign language pedagogy, especially for young adult English learners, would benefit from applying word games in their vocabulary instruction and writing.
\end{abstract}

Key words: Word games, Iranian EFL learners, application of words, writing paragraph essays

\section{Introduction}

Psychologists, linguists, and language teachers have been interested in vocabulary learning strategies for a long time. Numerous studies have been conducted comparing the retention effects of different vocabulary presentation strategies. Vocabulary as a major component of language learning has been the object of many studies. Vocabulary is more than a list of words, knowing how to use it matters more. The goal of vocabulary instruction should be to make the learner aware of word meaning and importantly word use in writing. Writing has always been regarded as an important skill in the teaching and learning English as a Foreign Language (EFL) and one big problem for EFL learners is how to recall the learned words and use them in paragraph writing.

This study will investigate one of the most important issues in EFL instruction, i.e., vocabulary development and use in writing one paragraph essay. One of the most difficult aspects of learning a foreign language, particularly in an EFL context, is the retention and use of vocabulary in writing. To prevail this problem teacher can teach vocabulary through activities like word games, reinforcing the teaching points without boring the students. Traditional techniques for teaching vocabulary to intermediate and advanced learners might not be so effective. Also word games might be good tools for improving the ability to recall meaning and help them to learn how to use vocabularies in context. One way to see the overall task of vocabulary learning is through the distinction between knowing a word and using a word. In other words, the purpose of vocabulary learning should include both remembering words and the ability to use them automatically in a wide range of language contexts when the need arises (McCarthy, 1984). One of the important things is that this instruction can be integrated with other methods and may help students' learning to be increased specifically with regard to vocabulary achievement, that is using a method which not only helps the students to remember or know a word but also use it whenever necessary. 


\section{Review of the related literature}

\subsection{Some Definitions of Games}

A single definition of the word 'game' is difficult to find. All available definitions seem to be descriptions of the most common characteristics of games. It seems that as long as a certain activity is felt to be interesting, amusing, or entertaining, it is likely to be referred to as a game. Griffiths and Clyne (1995) state that the word diversion implies that a game is to be enjoyed. A game may be defined as an enjoyable diversion in which we test our skill, strength or chance, according to a set of rules. Allery (2004) defined a game as "a competitive activity with a prescribed setting, constrained by rules and procedures. The learning results from playing the game (for example, interactions and behaviours exhibited) and not from the academic content or specialist subject matter" (p. 504).

According to Hunt and Cain (1950) a game is:

- A way of behaving in play which tends to conform to a pattern that is generally formed and shared by several individuals;

- The game pattern is emphasized by the elements of organization which bring about a definite and often repeated climax;

- In a game, individuals do not lose their identity, for the game itself is a situation in which the elements of success and failure are so equally balanced that only players by their own efforts, practice, and application of self can swing the balance to succeed (pp. 31-32).

Harvey and Bright (1985) define an instructional game by the following characteristics:

- A game involves a challenge against either a task or an opponent;

- A game is governed by a definite set of rules;

- A game is freely engaged in;

- Psychologically, a game is an arbitrary situation clearly separate from real-life;

- Socially, the events of a game situation are considered, in and of themselves, to be of minimal importance;

- A game has a definite number of possible solutions; that is, only a finite number of things can happen during play;

The perception of what constitutes a 'language game' is that it shares some common aspects with games in general, but also has specific traits. 'Language games' is a general term used to cover a variety of language activities. Language games are used for practicing specific language items such as grammar, sentence structures, vocabulary, and spelling; and for developing language skills, such as listening, speaking, writing and reading.

\subsection{Conceptual Framework and Characteristics of Games}

The use of games as a teaching strategy has been widely adopted in different subject areas of the curriculum, such as mathematics (Downton, 2004; Markey, 1997), physics (Chandler, 1996), biology (Nemerow, 1996) and medicine and nursing (Anderson, 1998; Ogershok \& Cottrell, 2004). There has also been a tendency toward a greater use of games in the language classroom. Many innovative language teaching methods, such as the Natural Approach (Terell, 1977), and Suggestopedia (Lozanov, 1979), - make use of language games.

Much has been written on the use of language games (Hong, 2002; Macedonia, 2005; Shie, 2003). Despite the growing interest in, and increasingly common use of games, relatively few empirical studies on the educational effectiveness of games have been conducted. Cortez (1974) and Gardner (1987), and Shie (2003) point out that most of the literature which discusses the value of using games in language classrooms has not been based on empirical research.

Generally, though, it can be argued that there is a gap in the research in this important area. Most of the studies on games have come out in favour of the usefulness of games. Among the very few to find no significant differences in the students' performance were those by Gardner (1987) and Miller (1992). Thus, it seems beneficial to test the widely accepted, but mainly untested, belief in the usefulness of games, also because it seems widely accepted that games increase the level of student motivation in the language classroom.

\subsection{Types of Language Games}

In the field of language teaching, the word 'game' has been a rather vague umbrella term for all kinds of activities considered to be fun. Research conducted by Shie (2003) confirms that it is difficult to group language games. Every author or practitioner classifies games according to different aspects, such as functions, language skills, techniques and organization. Littlewood (1981) and Hadfield (1996) divided language games in two main types: communicative and pre-communicative games. Below comes a definition of each. Communication games are those where the emphasis is on successful communication, rather than on grammatical correctness. Communication games cover such communicative functions as greeting, invitation, request, description, and narration, where the output is open-ended, unprescribed, or unpredictable.

Games that stress accuracy of language use are called pre-communicative games. As this type of games emphasize accuracy of language use, they have explicit definitions, such as "structural games" (Hadfield, 1996), or more direct "grammar games" (Ur, 1988; Steinberg, 1992). The aim of structure-aimed games is to foster the linguistic ability for certain syntactic patterns, some vocabulary areas and idiomatic expressions, spelling and pronunciation skills and new vocabulary. In pre-communicative games, the participants' output is close-ended to ensure the correctness of language 
use. A further subdivision of language games, both communicative and pre-communicative, can be made on the basis of specific aspects such as (a) cooperation and competitiveness (b) techniques.

\subsection{Learning through Games in Language Classrooms}

While acknowledging the risks associated with the use of games, such as noise and lack of discipline (Kuo, 1990), Richard-Amato (1996) advises teachers not to lose sight of the pedagogical value of games, particularly in second language teaching. Games are effective for helping students learn. Games make practice more effective as students become active participants in the learning process (Allery, 2004; Ruben, 1999; \& Thatcher, 1990). In addition to the improvement of learning outcomes, games are effective because they can lower students' stress, increase students' interest and motivation and give them the opportunity for effective communication (Allery, 2004; Ruben, 1999). These are all very positive reasons for playing games in the language classroom. This section presents the advantages of games, as they have been pointed out in the literature on their usefulness: active learning, improvement in retention, interaction, flexibility, motivation and supportive atmosphere.

\subsection{Games and Active Learning}

Games provide unique learning opportunities to meet students' needs while engaging in an active learning process (Allery, 2004; Anderson, 1998; Thatcher, 1990). Thatcher (1990) promotes games as a significant form of experiential learning. Allery (2004) also states that games "ensure all participants are winners in that all have the opportunity for involvement and to engage with experiential learning ... the role of the participant as an active processor of information" (p. 504). During a game, the learner is actually engaged in an experience in which resolutions or decisions must be made. Evaluation, discussion, reflection, and application all occur during playing games and all promote learning. Ruben (1999) states that active participation is the chief advantage of games. Games "accommodated more complex and divers approaches to the learning processes and outcomes; allowed for interactivity; ... perhaps most important, fostered active learning" (p. 500). Games allow the students to have active control of the learning process and also promote prompt feedback from their peers (Allery, 2004). Reinforcing and augmenting prior knowledge, while obtaining new information for basic problem solving, allows students the opportunity to use and apply newly acquired course material (Jones, Mungai \& Wong, 2002).

Also Holler (1996) explored the relation between retention and learning method. His findings agreed with the above writers. He also found that games are a valuable tool for enhancing learning. He stated that we remember only $10 \%$ of what we read, $20 \%$ of what we hear, $30 \%$ of what we see, $50 \%$ of what we both hear and see, $70 \%$ of what we say, but $90 \%$ of what we do. Traditionally, students have listened to explanations from their teachers and have completed homework exercises. If Hollers' work is taken seriously, it is possible to conclude that students cannot retain grammar rules for a long time, and so learning outcomes will be limited. Games provide more opportunities for students to practise in a meaningful linguistic situation. This contributes to greater retention and more satisfactory learning outcomes. There is some evidence that games may improve the retention of what is learned (Pierfy, 1977; Jacobs \& Dempsey, 1993). Pierfy (1977) reviewed twenty-two comparative studies of simulation games. On the basis of this work, Pierfy concluded that games encouraged greater retention over time than conventional classroom instruction, with students reporting more interest in the game activities. In their research, Cortez (1974), Issacs (1979) and WruckeNelson (1992) also confirmed the effectiveness of the use of games on their students' language skills.

\subsection{Motivation and Games}

A widely perceived advantage of language games is also their ability to improve student motivation (Deesri, 2002; Gaudart, 1999; Nemerow, 1996;). Researchers in social psychology and education have recognized the importance of motivation for successful L2 learning (Gardner, 1985; Gardner \& Clement, 1990; Nemerow, 1996). Nemerow (1996) points out the role of motivation by saying that "lack of motivation is probably the greatest obstacle to learning" (p. 3). Gardner's (1985) socio-educational model of second language acquisition focuses on language learning taking place in the classroom and stresses that motivation is one important variable important in second language acquisition. Language games can promote the learners' motivation not only through their changeable forms of activity and kaleidoscopic nature of engagement, but also through their positive effect on the level of anxiety. Games can lower learners' anxiety in the classroom and thus improve their learning. In conventional classrooms, there is a lot of stress put on students trying to master the target language. Schultz and Fischer (1988) argue that

Stress is a major hindrance in language learning process. This process [Learning language in traditional way] is by its nature time consuming and stress provoking... raises the stress level to a point at which it interferes with student attention and efficiency and undermines motivation. ... [The use of games] has been developed to make students forget that they are in class... they relax students by engaging them in stress-reducing task. (p. 7)

\subsection{Statement of the Problem}

The motivation for this study derived from observations made in various EFL teaching and learning situations in which new strategies for application of the learned words in paragraph writing need to be developed. One useful strategy for the application of words in writing is using games. Since the practicality of the learned words in the course is open to question, the researcher decided to do the research.

\subsection{Research Question}

In order to achieve the end of this study, the researcher proposes the following question and null hypothesis: 
Do word games have any significant impact on Iranian EFL intermediate students' application of the words in writing one paragraph essay?

\subsection{Research Null Hypothesis}

Word games do not have any significant impact on Iranian EFL intermediate students' application of the words in writing one paragraph essay.

\section{Methodology}

\subsection{Participants}

The participants were male and female intermediate level students from Jihad Sharif Institute in Tehran. In order to conduct the research the researcher invited 60 students to participate in this experiment. They formed 4 classes of 15 students on average, which made out for 60 learners in total. The students were at an intermediate level studying Top Notch series, book 3 part A, by Joan Saslow \& Allen Ascher (2006) which were taught in 16 sessions from Jihad Sharif Institute in Tehran in which the researcher has been teaching for two years.

\subsection{Instrumentation}

To achieve the purpose of the study, the researcher utilized certain instruments to measure the participants' abilities in terms of language proficiency, knowledge of vocabulary, and some instructional materials.

\section{PET Test}

The first testing instrument was Preliminary English Test (PET) consisting of different sections aimed at controlling the proficiency level of the subjects. The allotted time for this test was an hour and thirty minutes. This version of PET (2004) was used in order to select a homogeneous group of participants. The test includes skills of grammar and structure, reading and vocabulary, and writing. PET test was administered in order to obtain the subjects' proficiency level of writing and also the degree of homogeneity or equality existed between the two samples. Out of the test takers two homogeneous groups of intermediate level students were selected as control and experimental groups.

\section{Test of Vocabulary}

Before exposing the subjects to treatment, a list including 60 words of those words they were going to learn, was given to ensure they did not know the words in advance. Those rare words which were answered by one-fourth of the participants were either omitted or replaced by some other new words. Learners were asked to write their synonyms, antonyms or Persian equivalent of each word.

\section{The Writing Post-test}

A post-test of paragraph writing was given to compare the learners' performance in both the experimental and the control group. The learners were asked to write five paragraphs on five topics of "Importance of Etiquette"," Kinds of Health Care You Use", "Write a Story of a Man's Day, Based on a Complex Illustration"," Recount the Work and Life Decisions You Have Made and Explain Any Regrets"," Describe a Holiday Tradition in Your Country" each in one paragraph.

\section{The Writing Rating Scale}

The writings were measured based on PET rating scale from 0-5 which checked paragraphs in content, grammar and vocabulary use. Since our focus was on the application of words in writing, the words accuracy of application was measured based on their correct parts of speech and correct use of the collocations.

\subsection{Procedure}

The study followed a quasi-experimental design and the two homogeneous groups of intermediate level students were selected by intact group design (convenient sampling). Prior to the main study is pilot study. The test was administered to pilot group to measure item analysis. Thirty participants with the same characteristics of our participants were selected to standardize the homogenization test (PET) and malfunctioning items that were the most difficult and easiest items were discarded and the reliability of the test before and after discarding malfunctioning items would was calculated. Then the Preliminary English Test was employed to homogenize participants regarding their proficiency in English. The scores which are +1 and -1 standard deviation above and below the mean were considered as intermediate. Those who met the criteria were divided into two equal groups: experimental and control. Before exposing the subjects to treatment, a list of those words they were going to learn, was given to make sure they did not know the words in advance. During the term, the teacher taught the words to both experimental and control groups. Through a regular teaching procedure, the words of five units of Top Notch 3 were taught to control group traditionally by giving teacher's definition of the words, synonyms and antonyms and repetition, as placebo. The experimental group received the treatment, which was the word game. Word games were used to reinforce what had already been taught. The experimental group received the word games at the end of each session about 30 minutes to reinforce learning. After 16 educational sessions a writing test of five single paragraph essays according to the topics of five units of Top Notch 3 as posttest was administered in each group. The purpose of the present study was to investigate the impact of the application of vocabulary language games on using the learned words in writing one paragraph essay.

The PET test was administered in order to homogenize the participants. The writings were measured according to PET rating scale from $0-5$ that checked paragraphs in content, grammar and vocabulary use. Then word games were offered as treatment to experimental group, a placebo was offered to control group. Finally after 16 educational sessions a test 
of writing as posttest was administered in each group. Instructional material were a set of word games and the course book used in this study was Top Notch, book 3 part A by Joan Saslow \& Allen Ascher (2006). Out of the test takers two homogeneous groups of intermediate level students were selected as control and experimental.

\section{Results and Discussions}

The statistical analyses conducted in the present study were specified based on the nature of the study, which was quasiexperimental research. The researcher used the following data analyses.

\subsection{Data Analysis for the PET (2004) as the homogeneity test}

To make sure that the participants of both groups were homogenous regarding their general English language proficiency, a PET test was administered to the participants of both groups.

The descriptive statistics for the two groups are displayed in following tables (see appendix A for further information).

Table 4.1. The Descriptive statistics of the PET test by the two groups

\begin{tabular}{|c|c|c|c|c|c|c|c|c|}
\hline & $\mathrm{N}$ & Range & Min & Max & \multicolumn{2}{|c|}{ Mean } & Std. Deviation & Variance \\
\hline & Statistic & Statistic & Statistic & Statistic & Statistic & $\begin{array}{l}\text { Std. } \\
\text { Error }\end{array}$ & Statistic & Statistic \\
\hline $\begin{array}{l}\text { PET Cont } \\
\text { Proficiency }\end{array}$ & 30 & 16.00 & 56.00 & 72.00 & 64.50 & .73461 & 4.02364 & 16.190 \\
\hline $\begin{array}{l}\text { PET Exp } \\
\text { Proficiency }\end{array}$ & 30 & 18.00 & 55.00 & 73.00 & 64.20 & .82962 & 4.54404 & 20.648 \\
\hline
\end{tabular}

Table 4.2. The Descriptive statistics of the PET test by the two groups

\begin{tabular}{|c|c|c|c|}
\hline & & PET Cont Proficiency & PET Exp Proficiency \\
\hline \multirow[t]{2}{*}{$\mathrm{N}$} & Valid & 30 & 30 \\
\hline & Missing & 0 & 0 \\
\hline & & 64.5000 & 64.2000 \\
\hline & & 65.0000 & 64.5000 \\
\hline & & $60.00^{\mathrm{a}}$ & 65.00 \\
\hline & viation & 4.02364 & 4.54404 \\
\hline & & 16.190 & 20.648 \\
\hline & & 56.00 & 55.00 \\
\hline & & 72.00 & 73.00 \\
\hline $\mathrm{Su}$ & & 1935.00 & 1926.00 \\
\hline
\end{tabular}

a. Multiple modes exist. The smallest value is shown

As seen in tables 4.1 and 4.2 above, the mean scores for the PET proficiency test are 64.50 and 64.20 for the control and experimental groups respectively, with the standard deviation of 4.02 and 4.54 .

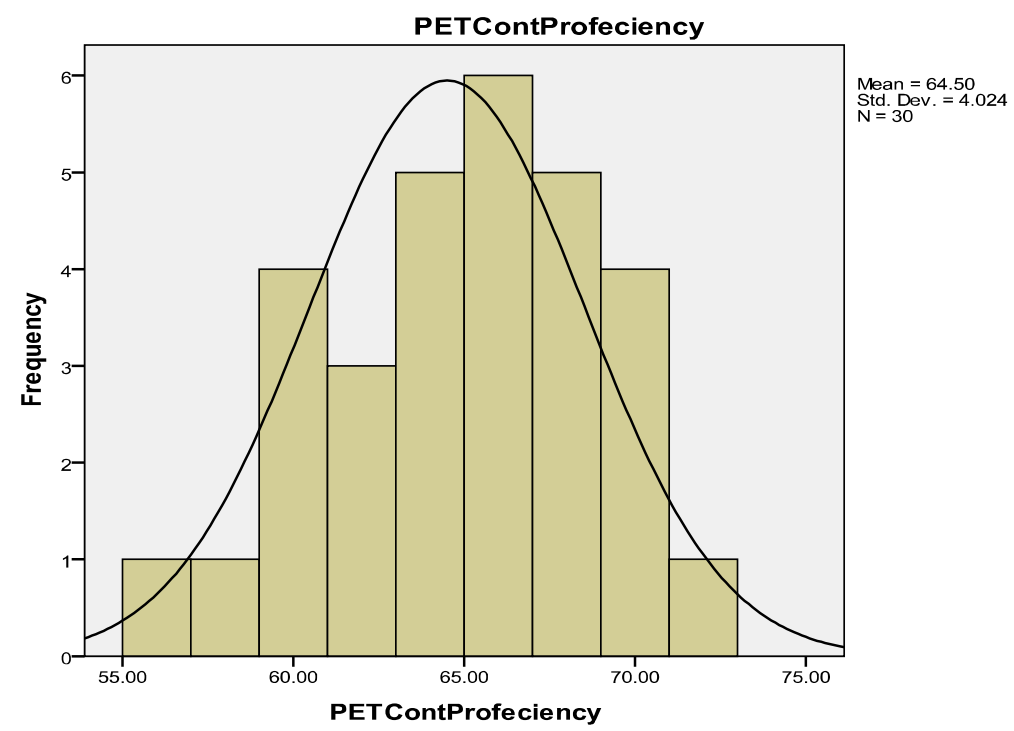

Figure 4.1. The histogram of the PET test by the control group 


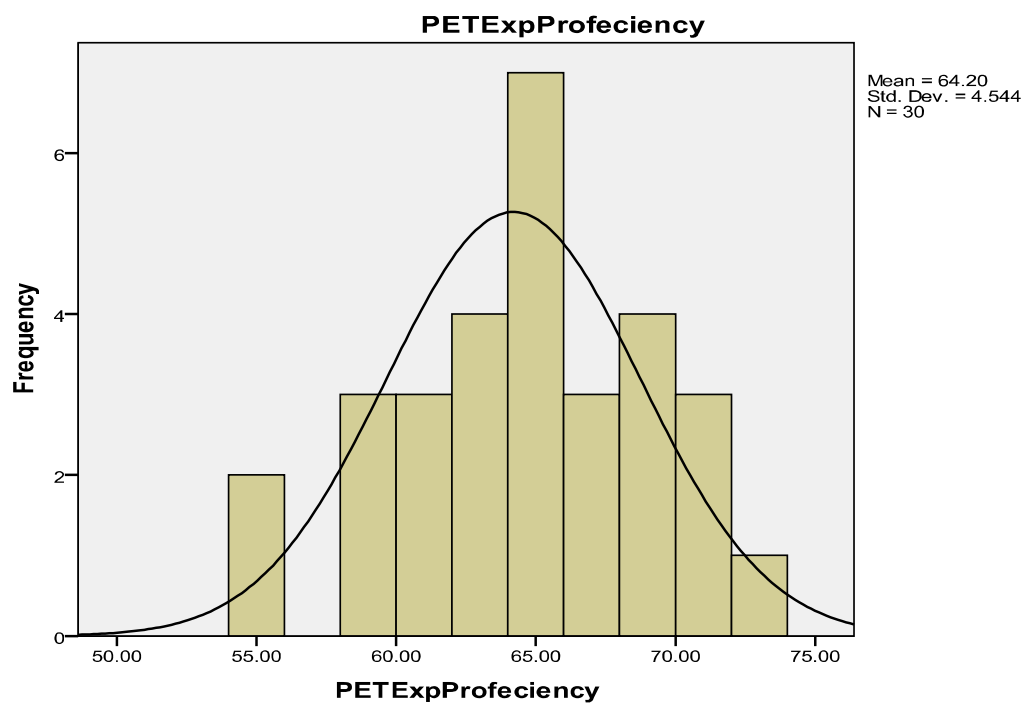

Figure 4.2. The histogram of the PET test by the experimental group

\subsection{Inter-rater reliability of the post-test}

Two different raters rated the students' performance on the posttest of writing in terms of its accuracy of application of vocabulary (collocation and part of speech). The following tables show the inter-rater reliability.

There is a significant agreement between the two raters who rated the students' performance.

Table 4.3. Post-test of writing $(\mathrm{R}=.83 ; \mathrm{P}=.000<.05)$

\begin{tabular}{lcc}
\hline & POSTWRITINGRATER2 \\
\hline \multirow{2}{*}{ POSTWRITINGRATER1 } & Pearson Correlation & $.838^{* *}$ \\
& Sig. (2-tailed) & .000 \\
& $\mathrm{~N}$ & 68 \\
\hline
\end{tabular}

As it can be seen in table 4.3 above, the probability value is .000 and the reliability is .83 which shows a good reliability between the two raters.

\subsection{Data Analysis for the game word writing section as the Post-test}

Table 4.4. Descriptive statistics for the writing post-test

\begin{tabular}{|c|c|c|c|c|c|c|c|c|c|c|}
\hline \multirow{2}{*}{ Group } & $\mathrm{N}$ & Min & Max & Mean & $\begin{array}{c}\text { Std. } \\
\text { Deviation }\end{array}$ & Variance & \multicolumn{2}{|c|}{ Skewness } & \multicolumn{2}{|c|}{ Kurtosis } \\
\hline & Statistic & Statistic & Statistic & $\begin{array}{c}\text { Statisti } \\
\text { c }\end{array}$ & Statistic & Statistic & Statistic & $\begin{array}{l}\text { Std. } \\
\text { Error }\end{array}$ & Statistic & $\begin{array}{l}\text { Std. } \\
\text { Error }\end{array}$ \\
\hline Experimental & 30 & 73.00 & 84.00 & 79.800 & 3.22062 & 10.372 & -.079 & .427 & -.851 & .833 \\
\hline Control & 30 & 61.00 & 78.00 & 71.300 & 4.29233 & 18.424 & -.305 & .427 & -.740 & .833 \\
\hline
\end{tabular}

In order to run a t-test, the researcher had to meet the two assumptions of normal distribution of scores and homogeneity of variances. As shown in table 4.6 above, the two groups were normally distributed because the ratios of skewness statistic over standard error were within the range of plus and minus 1.96. So, the first assumption was met.

It should be noted that the two groups were also homogenous in terms of their variances. As displayed in Table 4.7, the Levene F of 3.384 had a probability of .071 . Since the probability associated with the Levene F was higher than the significance level of .05 , it could be concluded that the two groups enjoyed homogenous variances on the post-test of word game writing. 


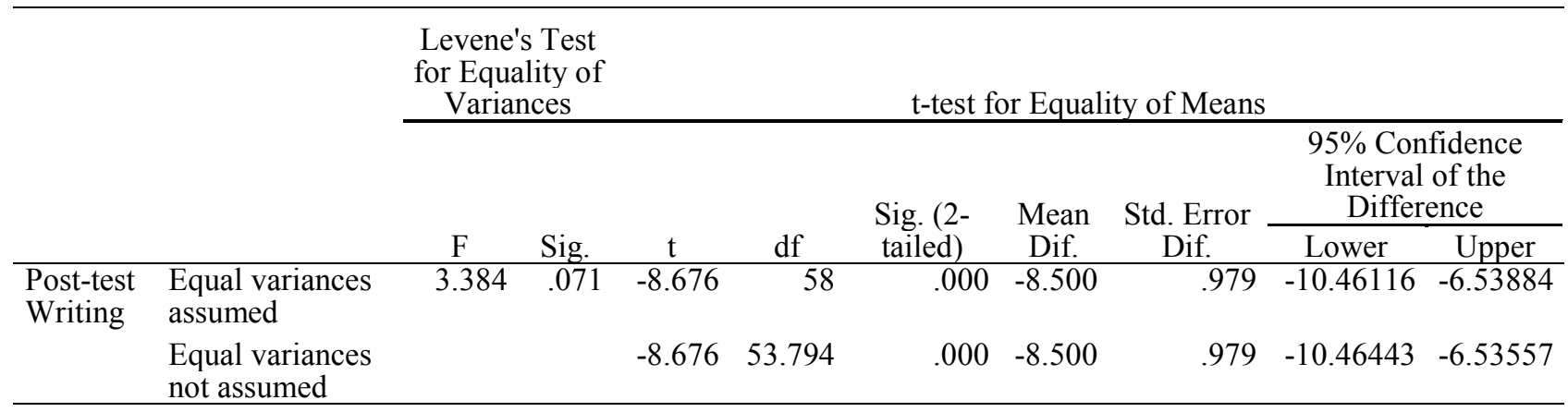

\subsection{Testing the null hypothesis}

The mean scores for the experimental and control groups were 79.80 and 71.30 , respectively. The $P$ value $=.000<$ .05). Based on the results, it could be concluded that there was a significant difference between the mean scores of the two groups on the posttest of word game writing test. The experimental group scored higher marks than the control group. According to the statistics, the mean difference was significant, therefore, it can be concluded that our null hypothesis which was "word games do not have any significant impact on Iranian EFL intermediate students' application of the words in writing one paragraph essay" has been rejected.

\section{Conclusions and Implications}

As it was mentioned earlier, the motivation for this study derived from observations made in various EFL teaching and learning situations in which new strategies for application of the learned words in paragraph writing need to be developed. One useful strategy for the application of words in writing is using games. There are different methods used for teaching a language as well as its vocabulary to EFL learners; one such way is using word games which may have deficiencies in teaching grammar or communicative skills but can be really helpful in teaching vocabulary of other subject matters to students. Therefore, this study aimed to find an answer to the following research question and null hypothesis:

Q: Do word games have any significant impact on Iranian EFL intermediate students' application of the words in writing one paragraph essay?

HO: Word games do not have any significant impact on Iranian EFL intermediate students' application of the words in writing one paragraph essay.

The research results rejected the stated hypothesis meaning that there actually is a significant difference between those students who work with word games and those who do not and unprecedentedly exceeded the researcher' expectations. But surprisingly the author found that not all the participants were in fact in favor of the word games. The reason might be the students were not used to being taught under this situation. This study investigated one of the most important issues in EFL instruction, i.e., vocabulary development and use in writing one paragraph essay. One of the most difficult aspects of learning a foreign language, particularly in an EFL context, is the retention and use of vocabulary in writing. To prevail this problem teacher can teach vocabulary through activities like word games, reinforcing the teaching points without boring the students. Traditional techniques for teaching vocabulary to intermediate and advanced learners might not be so effective.

In Iran, learning vocabulary has been considered a boring subject for a long time and the traditional way of learning vocabulary by mere copying and remembering has shown to be less than effective. Meanwhile, games are also seen as a time-filling activity in most English classrooms. It is believed that games are just for fun and they have very little effect in teaching and learning. However, this research revealed that games contribute to vocabulary learning if they give students a chance to learn, practice and to review the English language in a pleasant atmosphere. From the research, it was found that students were demanding new ways of learning vocabulary, and they themselves are in search of new ways of learning this subject as well.

Interpretations of the findings of this research also led to several suggestions for further research.

1. It is recommended that this study be replicated with a larger sample or number of participants from the same background. This study considered around sixty people which is not a large sample.

2. The present study may be replicated having native speakers as the participants, so that the efficacy of using word games would be explored on the native speakers as well.

3. It is recommended that a concept mapping or a visual map study be conducted on the effect of vocabulary learning of Iranian EFL learners.

4. It would be interesting to compare the results across levels of proficiency.

5. It is recommended that the picture-based vocabulary teaching study be conducted in order to investigate the possible effect of pictures on the retention of vocabularies as well. 
Allery, L. A. (2004). Educational games and structured experiences. Medical Teacher, 26(6), 504-505. doi:10.1080/01421590412331285423

Anderson, K. S. (1998). Let the game begin: The gaming approach as an alternative paradigm in nursing education. Unpublished Ph.D. dissertation, North Carolina State University, North Carolina.

Chandler, T. (1996). Reflections and further questions. Retrieved from global .umi.com/pqdweb?INT $=0 \&$ SelLanguage $=0 \& T S=1043287741 \&$ Did $=000$

Cortez, E. G. (1974). Games for second language learning: A comparison of two approaches for teaching English to Puerto Rican children. Unpublished Ph.D. dissertation, Temple University, PA.

Deesri, A. (2002). Games in the ESL and EFL class. Retrieved from http://iteslj.org/Techniques/Deesri-Games.html.

Downton, A. (2004). Games can help get reluctant learners into maths. EQ Australia, 3, 17-19.

Gardner, D. (1987). Communication games: Do we know what we're talking about? ELT Journal, 41(1), 19-24. doi:10.1093/elt/41.1.19

Gardner, R. C. (1985). Social psychology and second language learning: The role of attitudes and motivation. London: Edward Arnold.

Gardner, R. C, \& Clement, R. (1990). Social psychological perspectives on second language acquisition. In H. Giles \& R. St. Clair (Eds.), Language and Social psychology (pp. 218-243). Oxford: Blackwell Press.

Gaudart, H. (1999). Games as teaching tools for teaching English to speakers of other languages. Retrieved from http://sag.sagepub.com/cgi/content /abstract/30/3/283.

Griffiths, R., \& Clyne, M. (1995). Games: A context and a medium for learning. In J. Wakefield \& L. Velardi (Eds.), Celebrating mathematics learning (pp. 191-195). Melbourne: The Mathematical Association of Victoria.

Hadfield, J. (1996). Elementary communication games: A collection of games and activities for elementary students of English. England: Wesley Longman.

Harvey, J. G., \& Bright, G. W. (1985). Basic math games. Palo Alto, California: Dale Seymour Publications.

Holler, J. (1996). Das neue Gehirn. Padeborn: Junfermann.

Hong, L. (2002). Using games in teaching English to young learners. Retrieved from http://iteslj.org/Lessons/LinUsingGames.html

Hunt, S. E., \& Cain, E. (1950). Games - the world around: Four hundred folk games. New York: A. S. Barnes Com.

Isaacs, R. H. (1979). Affective and cognitive changes in using Hebrew language games with thirteen and fourteen year old students: An exploratory study. Unpublished Ph.D. dissertation, Columbia University Teachers College, New York, NY.

Jacobs, J. W., \& Dempsey, J. V. (1993). Simulation and gaming: Fidelity, feedback, and motivation. In J. V. Dempsey \& G. C. Sales (Eds.), Interactive instruction and feedback (pp. 197-227). Englewood Hills, NJ: Educational Technology Publications.

Jones, D., Mungai, D., \& Wong, L. (2002). Games to teach. Paper published in the proceeding of the 18th Annual Conference on Distance Teaching and Learning, Wisconsin, UW.

Kuo, Y. (1990). Using some selected games to develop secondary school students' oral communication skills in Taiwan. Taipei: The Grane Publishing.

Littlewood, W. (1981). Communicative language teaching. Cambridge: Cambridge University Press.

Lozanov, G. (1979). Suggestology and outlines of suggestopedy. New York: Gorden \& Breach Science Pub.

Macedonia, M. (2005). Games and foreign language teaching. Support for Learning, 20(3), 135-140. doi:10.1111/j.0268-2141.2005.00377.x

Markey, C. E. (1997). An investigation into the use of structured games to teach early fraction concepts to students who are deaf or hard of hearing. Unpublished master's thesis, Griffith University, Queensland, Australia.

Miller, M. C. (1992). Two experimental studies of the effectiveness of interactive game-playing in the acquisition of Japanese by Americans. Unpublished doctoral dissertation, University of Delaware.

Nemerow, L. G. (1996). Do classroom games improve motivation and learning? Retrieved from http://global.umi.com/pqdweb?INT $=0 \&$ Sel Language $=0 \& T S=1043287741 \&$ Did $=000000$.

Ogershok, P., \& Cottrell, S. (2004). The pediatric board game. Medical Teacher, 26(6), 514-517.

Pierfy, D. A. (1977). Comparative simulation game research: Stumbling blocks and stepping stones. Simulation and Games, 8(2), 255-268.

Richard-Amto, P. A. (1996). Making it happen. New York: Addison-Wesley Publishing Group.

Ruben, B. D. (1999). Simulations, games, and experience-based learning: The quest for a new paradigm for teaching and learning. Simulation \& Gaming, 30(4), 498-506. doi:10.1177/104687819903000409

Schultz, M., \& Fischer, A. (1988). Games for all reasons. New York: Addison-Wesley. 
Shie, J. S. (2003). Aspects of EFL games. Taipei: The Crance Publishing Company.

Steinberg, J. (1992). Games language people play. Ontario: Dominie Press Pippin Publishing Limited.

Terrell, T. D. (1977). A natural approach to second language acquisition and learning. The Modern Language Journal, 61, 325-336. doi:10.2307/324551

Thatcher, D. C. (1990). Promoting learning through games and simulations. Simulation \& Gaming, 21, 262-273. doi:10.1177/1046878190213005

Ur, P. (1988). Grammar practice activities: A practical guide for teachers. Cambridge: Cambridge University Press.

Wrucke-Nelson, A. C. (1992). An investigation into the development of oral English in concept formation through the use of group games in the bilingual/ESL classroom. Unpublished Ph.D. dissertation, Texas Woman's University, TX. 